\title{
Nietzsche, Hegel and Historicism: A Polemic With Foucault's Reading of Nietzsche
}

\author{
Paul Catanu, $\mathrm{PhD}$ \\ Humanities Instructor, Champlain College, St-Lambert
}

\section{1) Introduction}

In this paper, we look at how Nietzsche handles the problem of history and historicism. The writing of history and thus indirectly, historicism itself, has a long and complicated history, which can perhaps be dated back to Hesiod, Homer and Herodotus. However, it is useful to distinguish when debating the problem of historicism between the classical historicism of the $19^{\text {th }}$ century German historical school (Ranke, Droysen, von Treitschke and, later, Meinecke and Troeltsch) and the later "new historicism" of thinkers such as Foucault and Derrida. Of course this does not exhaust the problem of historicism which made repeated reoccurrences in philosophical life in the works of Dilthey, Husserl and even Rickert and Windelband, not to speak of Gramsci and Lukács. However, given the limitations of space of this paper, I mainly analyze how historicism occurs in Nietzsche's philosophy and his position vis-à-vis it.

More specifically, I will discuss Nietzsche's concept of history, and his alleged connection to historicism, both by looking back at how he reacted to the German historical school and how his thought influenced the later French thinker Foucault. I will also discuss the connection between the concept of Becoming and Nietzsche's alleged historicism.

There is a tension between Nietzsche's earlier writings on history (Fatum and History, Free-will and Fatum, The Untimely Meditations) and the later writings in which a genealogical concept of history is developed. This tension has been noticed by many commentators amongst which the most famous is probably Michel Foucault. However Foucault would have us believe that there is a continuity of the philosophy of history espoused by Nietzsche in the Untimely Meditations and in the Genealogy of Morals. I believe that this reading of Foucault's, which is especially expounded in
Nietzsche, Genealogy, History, is essentially a misreading and I will try to show why.

I will argue that there is a continuity between the Untimely Meditations and Thus Spoke Zarathustra and that this continuity sketches an anti-historicistic position within Nietzsche's philosophy. This anti-historicistic position is articulated around Nietzsche's key concepts of the supra-historical, the eternal and the Augenblick.

2) Differences Between the Early and the Late Nietzsche's Views On Historicism and History

In the Second Untimely Meditation, Nietzsche defines culture as "the stylistic unity of the artistic expressions of a people". This unity alluded to by Nietzsche is present throughout the Second Untimely Meditation. Nietzsche identifies the dichotomy between substance and form, between inner and outer, as the problem affecting modern culture. One needs to distinguish Nietzsche's classicism from that of Hegel, as it is most clearly expressed in his Lectures on Aesthetics. Hegel still operates with the balance between form and content, Being and appearance that is characteristic of ancient Greek culture. In Nietzsche, there is a tragic rupture between Being and appearance, between form and substance. In the early writings, and this includes the Second Untimely Meditation, Nietzsche still experiences the loss of balance between form and substance as a tragic rupture and a problem.

One could define historicism as the belief that all manifestations (ideas, concepts, institutions, texts and, ultimately, Being itself) need to be understood starting from their historical context. This would be the broadest definition of historicism. From there one could proceed to refine the concept of historicism into sub-categories. Hegel would be a historicist in virtue of believing 
the previous definition to be true, but he also believes that history has a telos or purpose. The German historical school is historicistic insofar as it believes the basic definition, but it also believes that one can establish a form of objectivity with respect to historical manifestations. Finally even Foucault and Nietzsche might be historicists according to the general definition. Of course the last two do not subscribe either to the idea of a goal of history or to the idea of an objectivity of history.

As concerns Foucault there is no doubt that he made overtures towards his own special brand of genealogical historicism, but I believe that we need to differentiate within Nietzsche's evolution between the generally historicistic phase of the Genealogy and the anti-historicism of the Untimely Meditations and of Thus Spoke Zarathustra.

The Second Untimely Meditation may be said to have a historicist moment. The monumental aspect of history, as Nietzsche describes it, presents the danger of leading to an over-evaluation of the past with respect to the present. There are also Hegelian-dialectical accents to the Second Untimely Meditation with its insistence on a German spiritual unity. Nietzsche, although differing from Hegel, is also a classicist insofar as he takes antiquity and more precisely the tragic age preceding Attical classicism as a model that can inform and criticize the present.

Nietzsche is influenced by Schopenhauer when he rejects Hegel's thesis on the identity between Being and appearance. This dichotomy between Being and appearance pushes Nietzsche to partly reject classicism and the idea of antiquity as a model. For Hegel, antiquity is classical insofar as it consists in a perfect coincidence between inner and outer, essence and manifestation, thing in itself and phenomenon. For Nietzsche, following Schopenhauer, the classical consists in the impotence to achieve the balance, unity and identity between inner and outer, essence and manifestation. Antiquity still functions as a model in Nietzsche, albeit as a model characterized by rupture and imbalance.

In the later writings however, history is conceived genealogically and as decadence or nihilism. Nietzsche develops a genealogical concept of history in the Genealogy of Morals by referring to the concepts of origin (Ursprung,
Herkunft and Entstehung). ${ }^{1}$ History conceived as genealogy is essentially pluralistic. There is no grand narrative of history as in Hegel. Genealogical history undermines the possibility of a world-historic, universal History. According to the genealogical conception, there is no History, only histories. The unity bemoaned by Nietzsche in the Second Untimely Meditation is radically undermined by the genealogical conception of history. ${ }^{2}$

Genealogical history functions by analyzing the hidden, protracted roots of a historical phenomenon. It seeks what lays dormant and what is covered over as the origin of manifestation of the historical phenomenon. However, a historical phenomenon is explained in the German historical school as being the function of a unity and continuity of the Western world that manifests itself in history. For genealogical thought the origin of a historical phenomenon is not manifest and not unitary. A genealogical account of history consists in a genetic account of an event that always seeks a plural and multi-shaped origin.

In the Genealogy of Morals, Nietzsche conceptualized history as the struggle between the slave and the master moralities. This can be seen as a covert polemic with Hegel for whom the master-slave dialectic constitutes a fundamental figure in the architectonic of the Phenomenology of Spirit. For Hegel, it is ultimately the slave that wins the struggle for recognition because, being more in touch with the earth, he is more natural than the master. For Nietzsche, the master is more active as opposed to the slave who is deemed to be reactive.

Nietzsche and Hegel both agree that the history of the West must be understood in terms of the struggle between the master and the slave figures or moralities. But their visions of this history are fundamentally at odds. The struggle between the master and the slave moralities can be re-translated, for Nietzsche at least, and in the Genealogy, as the struggle between Rome (master)

\footnotetext{
1 Ursprung=Origin with the exact meaning "original jump"; Herkunft=origin with the exact meaning of "past origin" or "heritage", and Entstehung=origin with the exact meaning of "coming-to-be". See Michel Foucault, Nietzsche, Genealogy, History, in Language, Counter-Memory, Practice: Selected Essays and Interviews, Translated from the French by Donald F. Bouchard and Sherry Simon, Ithaca, N.Y., Cornell University Press, 1977.

$$
H L, 4,(K S A 1, \text { p.278). }
$$
}


and Judea (slave). For Nietzsche, the relationship between the master and slave moralities does determine the history of the West fundamentally ${ }^{3}$, but this determination is not conceptualized through an act of recognition.

The master does not need the recognition of the slave, he does not envy the desire of the slave in order to be essentially that which he is: active. Rather the being-active of the master is not defined in terms of a conscience that opposes him and against which this master must risk his own life. The master is free and active because he does not possess the moral conscience of the slave that determines the slave's essential reactivity.

\section{3) The Young Nietzsche's Anti-Historicism}

Gadamer's thesis is that Nietzsche's philosophy did not sprout from the soil of German Idealism as much as in reaction to German historicism. ${ }^{4}$ Nietzsche discusses historicism in his famous Second Untimely Meditation. There, Nietzsche identifies history and the study of history as an illness that prevents man from acting. Action is opposed to knowledge as in Hamlet's classical dilemma. $^{5}$ To know the state and true nature of Being entails being opposed to the action that is associated with Becoming.

In this sense the Dionysian man has similarities to Hamlet: both have had a real glimpse into the essence of things. They have understood the nature of reality, and it disgusts them to act, for their action can change nothing in the eternal nature of reality. They perceive as ridiculous or humiliating the fact that they are expected to set right again a world, which is out of joint. Knowledge kills action... ${ }^{6}$ History and knowledge

\footnotetext{
3 This is implicit in Nietzsche's theses about the master and slave moralities that are developed in the first essay of On a Genealogy of Morals.

$4 \quad$ See footnote 229 in Wahrheit und Methode, p.130.

"Thus conscience does make cowards of us all; and thus the native hue of resolution is sicklied o'er with the pale cast of thought; And enterprises of great pith and moment, With this regard, their currents turn awry, And lose the name of action." Shakespeare, W., Hamlet, Prince of Denmark, Act III, Scene I.
}

${ }^{6} \quad$ In diesem Sinne hat der dionysiche Mensch Ähnlichkeit mit Hamlet: beide haben einmal einen wahren Blick in das Wesen der Dinge gethan, sie haben erkannt, und es ekelt sie zu handeln; den ihre Handlung kann nichts am ewigen Wesen der Dinge ändern, sie empfinden es als lächerlich, dass ihnen zugemuthet wird, die Welt, die aus den Fugen ist, wieder einzurichten. Die Erkenntniss tödet das Handeln...GT, 7, (KSA of history are opposed to action because in order to act, man has to forget. Essential to acting is an ability to forget one's past. For Nietzsche, acting is a projection onto Becoming and Becoming in its turn represents the immediacy of the moment as opposed to the sediments of historical Being.

Nietzsche's generalized perspectivism can be contrasted with Dilthey's positivism. In this way, this perspectivism is understood in relation to the problem of historicism. The aporia or contradiction generated by the problem of historicism can be expressed as follows: Human beings are aware that they are historical and that they live in different historical epochs. But the understanding of different historical epochs can only be achieved through the deforming lens of our own present epoch. This means that we can have no objective understanding of past historical epochs since we only perceive them through the lens of our present. Put this way, historicism can be understood as implying relativism. The dilemma can also be put otherwise. We are historical beings, therefore we inhabit a particular historical epoch but in virtue of inhabiting that particular historical epoch we have no access to the past epochs that are constitutive of our historicity.

History is presented as Becoming in the last great attempt to understand it philosophically. This is represented best by Hegel's Idealism. But this Becoming is understood as processuality, development and teleological movement. Nietzsche probably has Hegel in mind when he writes in the Second Untimely

A look at Nietzsche's and Hegel's philosophies shows clearly that history comes down to the old metaphysical problem of Being and Becoming. History is not possible without the movement of Becoming, but there are sediments, there are necessities: the flow of Becoming is constantified in Being. The place where the dialectical play of Being and Becoming occurs is precisely this History that we have been, that we have become, and that we never cease to become.

For Nietzsche, history is archaic, critical or monumental but it is also genealogical. Genealogy consists in the study of origins. The origin of history is not hypostasized but studied concretely in terms of its natural origins. The struggle

$1,56-57)$. 
between the master and the slave moralities is to a certain extent the motor of history. The problem is that there is more than one motor of history. To try to understand history solely in terms of a larger, essential process that occurs within it is already to distort history for Nietzsche. Another possible motor of history could be nihilism as has been claimed by Heidegger. But the problem with this description of nihilism is that it is part of the Heideggerian strategy-namely the claim that Nietzsche merely inverts the progress and actualization of freedom in history characteristic of Hegel's Idealism, by proposing a negative development that may be called the history of nihilism. This Heideggerian strategy is ultimately unsatisfactory and untenable since it leads to the radical historicization of Nietzsche's thought.

Some have argued that the paradoxy that characterizes historicism leads to its selfdestruction. The problem with historicism is that even though it recognizes the organicity of historicity it still attempts to find a perfectly objective grounding for its understanding of the past. The question of historicism can be reformulated as the question of whether history elevates a claim to truth.

However, for Nietzsche the question is whether history can serve life. We see here prefigured, a theme that is familiar for Nietzsche: the greater importance of life and the value of an evaluation for life over that of truth. Nietzsche does not explicitly apply the concept of force to his understanding of history but the translation of this concept into the realm of history is perhaps appropriate. It is probable that Nietzsche's usage of the concept of play of forces is owed to Fechner (Elemente der Psychophysik) or to Büchner (Kraft und Stoff).

In this sense, Nietzsche is thinking of forces as physiological and physical entities that have a material application. But the play of forces is also what constitutes the essence of will to power and in this sense these forces can be taken as a metaphysical substrate as well as a material one. Heidegger's reluctance to explain will to power in terms of the play of forces might indicate his awareness of the materialistic implications of such a concept.

But in Ranke's and Hegel's explanations of history, forces are clearly understood as spiritual and metaphysical entities. In Hegel force is related to its exteriorization. This exteriorization is in turn related to interiorization. Hegel shows that this play of exteriorization and interiorization that is the essence of self-consciousness can be subsumed under the concept of life. Interiorization is given priority in this description of self-consciousness and life but the relationship between exteriorization and interiorization is dialectical.

Life is also related to force for Nietzsche, but his analysis of force does not lead to a dialectic of life. Nietzsche deconstructs the interiorization of force that is the essence of life for Hegel. The interior interiorization and the exterior exteriorization of force cannot be seized dialectically. Rather, the essence of force precedes and destroys the still metaphysical opposition between interior and exterior, between inside and outside. History is understood in historicism as something that has meaning and that makes sense. There is a unity, a continuity, and a necessity behind the events of history. For Nietzsche, these three grounding concepts of unity, continuity and necessity of history have become problematic in the Genealogy of Morals.

\section{Zarathustra \\ 4) Anti-historicism in Thus Spoke}

In Thus Spoke Zarathustra, Nietzsche inaugurates an original way of thinking time and temporality and thus history. The key element that one has to retain in Nietzsche's magnum opus is the concept of the Augenblick or the eternity of the instant. What does it mean that eternity can be given in an instant? Eternity has two traditional acceptions: it can mean timelessness or it can mean a temporal endlessness or infinity. Even though both of these meanings are present in Nietzsche's concept of the Augenblick, we have to decide which of the meanings is more important.

The Nietzschean Augenblick is connected, in its redemptive power, with the thought of eternal recurrence of the same. In the moment when the eternal recurrence of the same is realized and understood, one reaches outside of history and of time. Eternal recurrence is connected to both Being and Becoming. Its aim is to redeem the past and transform and transfigure it into a perfectly willed present and future. Thus eternal recurrence is tied to the Delphic model of historical knowledge of the Second Untimely Meditation, which understood 
history according to inner need and to selfknowledge.

In the interpretation of the tale of eternal recurrence recounted in On The Face and the Riddle of Thus Spoke Zarathustra, we must part ways radically with Heidegger's interpretation of Nietzsche. Heidegger assumes that the "schwarze, schwere Schlange" that Zarathustra sees in the throat of the young Hirt (pastor) is the snake of nihilism. What the young Hirt needs to bite off and that is stuck in his throat is the thought of recurrence that is somehow amalgamated with the thought of nihilism.

If everything repeats itself then nothing is worth anything and all is indifferent (nihilism) and if everything repeats itself then everything matters, everything is worth something (eternal recurrence). The difference is very subtle between nihilism and eternal recurrence: one could call it one of existential nuance.

On the one side the repetition leads to meaninglessness whereas on the other it leads to the creation of meaning. But let us get back, to the "schwarze, schwere Schlange" that is stuck in the throat of the Hirt who is none other than Zarathustra himself. According to us this heavy black snake can only be the heavy black snake of time. Time is responsible for the will's ill will. The will is still captive because it cannot will backwards in time. What needs to be overcome when thinking the thought of eternal recurrence is time itself and not nihilism. Time is the deeper root of nihilism. It is because of time that the "upmost values lose their value". This is the case because, values are posited historically and later in other historical circumstances they may come to lose their value. But this historical process is inextricably linked to time and its "it was". Were it not for the temporal aspect of the past and for the inability of the will to will backwards and to redeem the historicity of the past, then the problem of nihilism would never occur.

This is why the Hirt must bite off the head of the snake, which represents time. If time can be overcome and the past redeemed, then nihilism can be overcome and eternal recurrence can be affirmed. But this interpretation of eternal recurrence also has consequences for Nietzsche's interpretation of history.

So how does the anti-historicism that operates in Thus Spoke Zarathustra, sit with the historicism of the Genealogy of Morals? The Genealogy is without a doubt one of the writings of Nietzsche that has been the most influenced by Darwinian naturalism. However one can still detect some antihistoricistic moments within it.

In fact the anti-historicistic moment of the genealogical method can be seen in the fact that by looking at the origins of a historical phenomenon, we realize its necessity. Of course, we also realize that the present phenomenon is contingent since it could have been otherwise had the historical, temporal positing been different. But insofar as genealogy opens the present for the future by looking at the past, it transforms and transfigures this present and makes it possible for the future to occur. Insofar as it does this, genealogy redeems both the past and the present by negating them and sublating them. Thus, genealogy has a negative dialectical quality that is also present in the eternal momentariness of the Augenblick.

\section{5) Consequences: Nietzsche contra Foucault}

It seems clear that the reading of Nietzsche on history that I am developing here is in many ways opposed to Foucault's reading of Nietzsche. Foucault has famously honed in on the concept of genealogy. I cannot hope to do a critique of Foucault's entire philosophical project, but I limit myself to the places where I think he appropriates Nietzsche unfruitfully or unproductively.

There is a danger in reading in Nietzsche a historical teleology of power. I think that despite Foucault's very sophisticated analyses of power he might have fallen pray to this danger to a certain extent. Foucault is certainly opposed to historical teleologies and he has made this clear in many places in his corpus. But perhaps Foucault does not distinguish enough between internal historical teleologies and external ones.

Even though Foucault's model of power is non-dialectical and functions from below, there is still a local teleology of power that operates within this concept and I think that this due to a misreading of Nietzsche's notion of power and history. The local, situated notion of power functions so as to perpetuate the regimes of rationality that are described by Foucault, but there is a telos that moves power toward its own increase. The emphasis on conditions of enhancement as being more important than 
conditions of preservation is certainly present in Nietzsche's conception of the will to power.

Foucault is also committed to having enhancement as a condition of power. If not Foucault's concept of power and history would be merely static and that, in itself, would be sufficient to discredit it to a great extent. Thus, it can be shown that there is a local teleology of power in Foucault's concept of power and in his conception of discontinuous history. But locality and local teleology is more fundamentally and clearly understood in terms of the traditional distinction between inner teleology and external teleology. This is the case, at least for Nietzsche if not for Foucault because, the will to power is constituted by Willlenspunktationen.

A Punktation is a draft of a contract or of a treaty in Austrian civil law. We say draft contracts or treaties and not treaty points of the will since then we would be coalescing the concept of Punkt with that of Punktation. The translation of Willenspunktation as "treaty points of the will" is also possible however since the draft contract or draft treaty is elaborated by listing points on which agreement is to be reached. In any case, we need to adjudicate as to whether it is the juridical-political nature of the concept of the will to power or its materialist/physicalist aspect that is of greater importance to Nietzsche in his concept of Willenspunktationen. The materialist aspects are favored by the fact that we could bring into proximity the concept of Kraft-punkt to that of Willenspunktationen. Ultimately we may not be able to adjudicate the real nature of Willens-punktationen because of the seldomness of its occurrence in Nietzsche's writings.

What is important for the concept of Willenspunktationen, insofar as it relates to Nietzsche's alleged teleology of power, is that the Punktation builds a global agreement based on a local point upon which agreement is reached. Thus, we proceed from the inside of the treaty through points, which construct externally from the inside out, the agreement/power structure. Thus locality is in fact understood on the model of an interiority of power that then leads to globality and to exteriority. But Nietzsche, takes the further step of deconstructing the Punktation and of claiming that the points of agreement have no existence in themselves. This lack of existence is predicated upon the fact that the points are in an eternal and infinite Becoming that can never be arrested in either, interiority or exteriority, locality or globality. Kraft-punkte, there is no overall stable increase of the will to power either globally or locally. Instead, the will to power infinitely aggregates and disaggregates itself at the power nodes and configurations of Becoming, perpetually transfiguring and transforming itself.

Thus, if the local-global pair concept is dependent on the inner-outter pair concept and if Nietzsche rejects an internalism of power, it is probable that he would have also rejected a localism of power. Foucault's notion of power is thus built upon and predicated on a misunderstanding of the relationhisp between genealogy and history within Nietzsche's thought.

Thus, it seems rather clear that the Foucaldian concept of an ontology of the present is opposed to Nietzsche's utopian conception of the philosophy of the future. This is the case because Foucault is opposed to a "suprahistorical perspective: a history whose function is to compose the finally reduced diversity of time into a totality fully closed unto itself'. But this is precisely what I have been arguing for, in terms of Nietzsche's opposition to historicism. The suprahistorical perspective is to be found precisely there in Thus Spoke Zarathustra, when the pastor (Hirt) attempts to round off time and close it upon itself in order to digest and overcome it. The serpent of past-time must be bitten off so that the will can will backward and incorporate and redeem the past.

Foucault's presentism (Habermas), the fact that he stubbornly concentrates on the present historical moment in order to think it through lead to his inability to think the future and to his radical historicism. Foucault' suspicion of the utopian tradition is understandable given the pre-Fall of Communism perspective and historical position from within which he was writing. There was no way to think through and conceive an exit out of late capitalism and the dual dynamic of the Cold War.

But this is precisely what is necessary at our present historical juncture. Utopia and utopianism has once more become necessary as a critical function for understanding how to move beyond the present and the past. For these purposes, the Nietzsche of the Untimely Meditations needs to be retrieved dialectically and it has to be shown that Nietzsche's dialectic of time and history in the 
Second Untimely Meditation is compatible with his later concept of genealogy. Genealogy is not in its essence historicistic. It does possess a dialectical quality insofar as it opens up the present by examining past origins.

By retrieving the past, criticizing and diagnosing the present and opening it up, genealogy makes the future possible. This is Nietzsche's legacy that Foucault has perhaps misunderstood to a certain extent given his suspicion of the dialectic and dialectical thought.

\section{6) Conclusion}

The late Nietzsche provides a genealogical and genetical account of history. He pluralizes the essentialized concept of history that is present in Hegel. The conscience of history is re-worked in the Genealogy as the tension between slave and master moralities. Through this move, Nietzsche goes beyond Hegel's mere integration of the master-slave dialectic into the movement of consciousness and self-consciousness. By reconceptualizing the relationship between slave and master moralities in terms of the concepts of reactive (slave) and active (master), Nietzsche advances beyond the merely dialectical conception of history that Hegel possesses. This is because for Hegel history embodies a purposive, unitary Telos whereas Nietzsche eliminates teleology from within Becoming (and thus from history).

However my thesis that there is an absolute, infinite and eternal Becoming within Nietzsche's philosophy does cohere with the analyzes presented in this paper. Despite having a historicistic moment, the Second Untimely Meditation also speaks of a supra-historical moment of World-history. This supra-historicity is in fact the seed of the infinite Becoming that we see at play in Nietzsche's philosophy. Becoming is infinite, eternal and absolute and the suprahistoricity of the Untimely Meditations, their exhortation to stand outside and above our epoch, is definitely something that comes into tension with the genealogical aspect of history of the Genealogy. In fact we have to look to Zarathustra to effectively decide what is more important for the mature Nietzsche's thought on history.

There we can see that despite the absence of a reference to Becoming, Nietzsche's philosophy wills and desires something beyond all else. What is this something that Nietzsche's philosophy wills and desires? It does not will and desire history and historicity but "all desire wills Eternity, wills deep, deep Eternity" ("alle Lust will Ewigkeit-, will tiefe, tiefe Ewigkeit", Zarathustra III, The Other Dance Song). 